\title{
Treatment of Chronic Spinal Cord Injury in Dogs Using Amniotic Membrane-Derived Stem Cells: Preliminary Results
}

\author{
Jéssica Rodrigues Orlandin' \\ Ingrid da Silva Gomes' \\ Shamira de Fátima Sallum \\ Leandro' \\ Artur Fuertes Cagnim' \\ Juliana Barbosa Casals' \\ Adriano Bonfim Carregaro' \\ Silvio Henrique Freitas ${ }^{\prime}$ \\ Luciana Cristina \\ Machado' \\ Maria Cristina Reis Castiglioni ${ }^{2}$ \\ Ana Liz Garcia Alves ${ }^{2}$ \\ Vânia Maria de Vasconcelos \\ Machado ${ }^{2}$ \\ Carlos Eduardo Ambrósio (1D) \\ 'Department of Veterinary Medicine, \\ Faculty of Animal Science and Food \\ Engineering (FZEA-USP), University of \\ São Paulo, Pirassununga, São Paulo, Brazil; \\ ${ }^{2}$ Department of Veterinary Medicine, \\ School of Veterinary Medicine and \\ Animal Science, São Paulo State \\ University (UNESP), Botucatu, São Paulo, \\ Brazil
}

Introduction: Intervertebral disc diseases (IVDD) represent the majority of neurological attendance and responsible for the most cases of paralysis in dogs. Treatments currently used do not show satisfactory results in patients with more severe and chronic neurological manifestations.

Methods: To promote nerve and muscular recovery, as well as improve quality of life, we aimed to create a double-blind test method, associating spinal decompression surgery and allogeneic transplantation of amniotic membrane-derived stem cells (AMSCs) in dogs with chronic IVDD. Cells were characterized as fetal mesenchymal cells and safe for application. Eight animals completed the experiment: stem cell applications were made in four animals that had previously undergone an unsuccessful surgical procedure ("SC group", n = 4); two animals were submitted to surgery, followed by applications of stem cells ("Surgery + SC", $\mathrm{n}=2$ ); two other animals were submitted to surgery, followed by the application of saline solution ("Surgery + placebo", $\mathrm{n}=2$ ). During the surgical procedure, a topical application was performed on the lesion and after fifteen and forty-five days another two applications were made via epidural. Animals were monitored biweekly and reassessed three months after surgery, by functional tests and magnetic resonance exams.

Results: Some animals presented significant neurological improvement, such as the recovery of nociception and ability to remain on station. Despite the need further studies, until the present moment, cell therapy has been feasible and has no harmful effects on animals.

Conclusion: The protocol of preclinical trial showed the association with decompressive surgery and cell transplantation in dogs with thoracolumbar IVDD proved feasible, and it was possible to observe neurological improvement after treatment. No tissue improvement through MRI was found. The double-blind test guaranteed reliability of the evaluations and results obtained that, even with a small sample size, generated satisfactory results for the animals and owners.

Keywords: cell therapy, spinal cord injury, discopathy, amnion, regenerative medicine

\section{Introduction}

Intervertebral disc disease (IVDD) is one of the most common causes of spinal cord compression and is responsible for most cases of paralysis in dogs. IVDD is characterized by the degeneration of the intervertebral disc and a neurological syndrome of compressive and/or contusive injury of the spinal cord that occurs due to the displacement of the disc or parts of it to the vertebral canal in a process known as herniation. ${ }^{1}$ According to Hansen, ${ }^{2}$ IVDD can be classified into two types: Hansen type I, characterized by extrusion of the material of the nucleus
Correspondence: Carlos Eduardo

Ambrósio

Email ceambrosio@usp.br 
pulposus into the vertebral canal, where it will cause spinal cord compression; and Hansen type II, resulting from the deformation of the disc, which causes the disc to protrude into the medullary canal. Recently, at least three other types of herniated discs have been described: hydrated nucleus pulposus extrusion; acute non-compressive nucleus pulposus extrusion; and intradural/intramedullary intervertebral disc extrusion. ${ }^{3}$

Olby et $\mathrm{al}^{4}$ developed a functional 0 - to 14 -point scale that evaluates gait, locomotor improvement and tail movement. A neurological exam was also performed, where mental status and behavior, body posture, gait, postural reactions, and cranial nerve and spinal reflexes were evaluated. The treatment of choice for animals affected by these conditions is based on decompressive surgical techniques, conservative treatment or rehabilitation. However, for the most severe patients, in almost $50 \%$ of cases, these treatments are still ineffective. ${ }^{5}$

The use of stem cells in regenerative therapy has raised positive expectations, specially the mesenchymal, that are easy to isolate and expand and differentiate into various lineages, allowing wide use for therapy regenerative. ${ }^{6,7}$ Owing to these expectations, several experimental models are being tested at both the molecular and preclinical levels to resolve doubts regarding the actual efficacy of the therapy, possible complications of its application, and especially the carcinogenic potential of these cells. ${ }^{8}$ These stem cells have characteristics of precursor cells and can be differentiated into several cell types and replicated. ${ }^{9}$ Thus, cell therapy has provided hope in the treatment of spinal cord injuries. ${ }^{10-18}$

The placenta performs primordial functions in the embryonic development of mammals since it is responsible for the protection, nutrition and oxygenation of fetuses. It consists of four membranes: the chorion, allantois, yolk sac and amnion. ${ }^{19,68}$

Amniotic stem cells demonstrate high plasticity and are able to self-renew and differentiate in vitro into chondrogenic, adipogenic and osteogenic lines. ${ }^{20-27}$ Gene expression and tumorigenic tests were performed on Balb/c nude mice and showed no evidence of tumor formation at 60 days after the application of amniotic stem cells, which were shown to be safe for application in this animal model. $^{27}$

Due to its immunomodulatory, anti-inflammatory, and regenerative effects, it is believed that cellular therapy is able to promote the modulation of the neuroinflammatory response ${ }^{28}$ and consequently of the glial scar, promoting functional and neurological improvement in animals.

In addition, this is the first study in veterinary medicine to use stem cells derived from the amniotic membrane in dogs with chronic non-iatrogenic spinal cord injury, representing a major innovation in the area, which can be translated to other species.

\section{Materials and Methods}

\section{Ethics Statement}

The use of stem cells and animals for this experiment has been approved by the Animal Ethics Committee of the Faculty of Animal Science and Food Engineering of the University of São Paulo, under protocol CEUA $\mathrm{n}^{\circ}$. 2274160216. Best practice guidelines for veterinary care were followed.

\section{Isolation, Culture and Cellular Cryopreservation}

Canine amniotic membrane stem cells were derived from a single elective ovariosalpingohysterectomy at approximately 50 to 60 days of gestation, as observed in Figure 1. The material was obtained from castration campaigns.

The isolation and cell culture protocol was adapted from Soncini et $\mathrm{al}^{29}$ and Lange-Consiglio et $\mathrm{al}^{24} \mathrm{In}$ a sterile laminar flow hood, the amniotic membrane was separated from the other fetal membranes and washed thoroughly with sterile PBS solution containing 2\% penicillin/streptomycin and 1\% amphotericin. The entire membrane was subjected to pre-digestion in dispase $(2.4 \mathrm{U} / \mathrm{mL})$ at $38.5{ }^{\circ} \mathrm{C}$ for 9 minutes. After this process, the samples were centrifuged at $200 \mathrm{xg}$ for 5 minutes. The pellet was resuspended in $0.1 \%$ collagenase and incubated at $38.5{ }^{\circ} \mathrm{C}$ for 3 hours. The mixture was centrifuged at $200 \mathrm{x}$ g for 10 minutes, and its supernatant was discarded. Ten milliliters of $\alpha$-MEM supplemented with $10 \%$ FBS and $1 \%$ penicillin/streptomycin was added, and this combination was passed through a $100 \mu \mathrm{m}$ filter and plated in $25 \mathrm{~cm}^{2}$ tissue culture flasks. The material contained in the filter was collected and subjected to enzymatic digestion by trypsin at $38.5{ }^{\circ} \mathrm{C}$ for 2 minutes. The digestion product was centrifuged at $200 \mathrm{x}$ g for 10 minutes, and the pellet was plated. The flasks were incubated at $38.5{ }^{\circ} \mathrm{C}$ with $5 \% \mathrm{CO}_{2}$ in an $80 \%$ relative humidity atmosphere. The cells were maintained until approximately $80 \%$ confluence (visual analysis by inverted microscopy). 


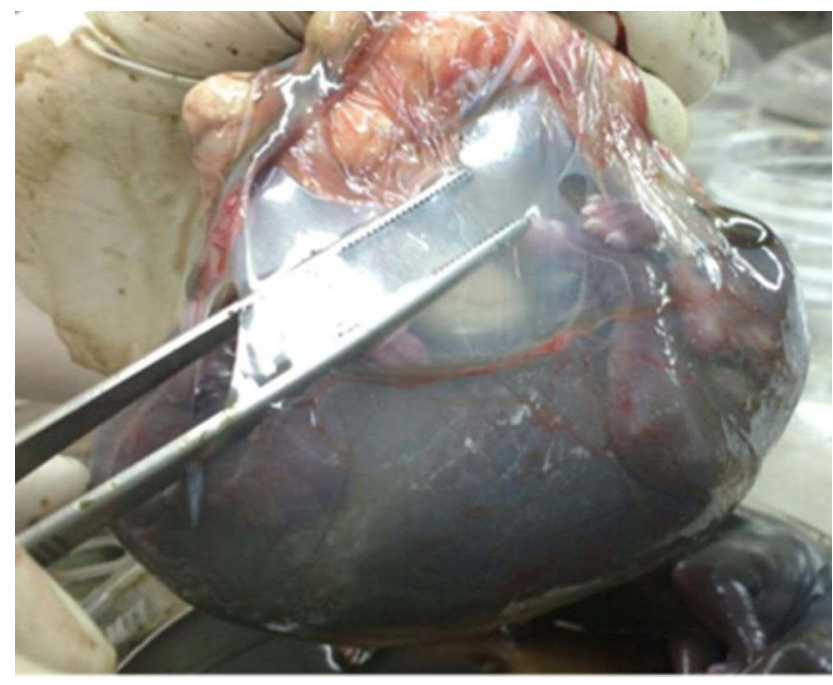

Figure I Isolation and cell culture. Final gestational-stage fetus, enveloped by amniotic membrane. The material was obtained from castration campaigns. Dissection was performed with sterile material followed by washing with phosphate-buffered saline (PBS) solution containing antibiotic.

In the cell passage process, the culture medium was discarded, $3 \mathrm{~mL}$ trypsin, previously heated in a water bath at $38^{\circ} \mathrm{C}$, was added, and the bottle was kept in an incubator at $38.5^{\circ} \mathrm{C}$. After a period of 3 to 5 minutes, the culture was evaluated by microscopy, and when no more cells were adhered, the resuspended cells were transferred to $15 \mathrm{~mL}$ Falcon-type tubes. More culture medium was added to the flask to perform a wash to aid in the removal of some cells that were still adhered, and later, that suspension was added to the tube corresponding to the respective bottle. The mixture was centrifuged at $200 \mathrm{x}$ g for 5 minutes. The supernatant was discarded, and the pellet was resuspended and replenished until it reached P2 or was cryopreserved.

For cryopreservation, the cells were trypsinized, resuspended in $1 \mathrm{~mL}$ of $\alpha$ MEM medium, counted in a Neubauer chamber and aliquoted so that each cryotube contained $2.5 \times 10^{6}$ cells diluted in $450 \mu \mathrm{L}$ DMEM F12 medium, $450 \mu \mathrm{L}$ FBS and $100 \mu \mathrm{L}$ DMSO. The cells were kept overnight in a Mr. Frosty container at $-80{ }^{\circ} \mathrm{C}$. After this period, the samples were transferred to a liquid nitrogen canister, where they were stored until use.

These cells were previously characterized by our group and published by Cardoso et $\mathrm{al}^{27}$ where they proved safe for application, according to the genetic expression and tumorigenic tests performed in Balb/c mice. The cells were prepared according to the protocol stipulated by Feitosa et al. ${ }^{13}$

Two random cryotubes were withdrawn from the liquid nitrogen and kept in a water bath at approximately $37^{\circ} \mathrm{C}$ for 2 minutes. The contents were transferred to $15 \mathrm{~mL}$ Falcon-type tubes, added to $1 \mathrm{~mL}$ of saline solution and centrifuged at $200 \mathrm{x} g$ for 5 minutes. The supernatant was discarded, and the pellet was resuspended in $1 \mathrm{~mL}$ of saline solution and again centrifuged at $200 \mathrm{x}$ g for 5 minutes. The pellet resulting from the procedure was resuspended in $1 \mathrm{~mL}$ of saline solution. Ten microliters of the final suspension were homogenized with $10 \mu \mathrm{L}$ of trypan blue dye and counted in a Neubauer chamber, totaling approximately $2 \times 10^{6}$ viable cells ( $80 \%$ viability).

The same protocol was performed as described above prior to the applications. The pellets were resuspended in $1 \mathrm{~mL}$ of saline solution and aspirated by an insulin syringe. For the placebo, the syringe was filled with $1 \mathrm{~mL}$ of saline solution. The solutions were inoculated in each animal according to the group to which the animal belonged.

\section{Experimental Design}

Twelve dogs that had chronic thoracolumbar IVDD for over one year, diagnosed clinically, through anamnesis, specific clinical examination, functional and neurological evaluation by the Olby scale ${ }^{4}$ and magnetic resonance imaging, were selected following a double-blinded protocol. Animals that presented other neurological diseases or any type of spinal trauma other than the lesion described previously were not included in the project. Twelve dogs were selected: 7 females and 5 males, age between 3 and 10 years old, with IVDD chronic from 12 to 17 months.

The owners of the selected animals signed a Free and Informed Consent Form, where they were informed about all the stages of the project, as well as their rights and duties. Four animals had already undergone to unsuccessfully decompressive surgery before, at least 12 months before. All these animals were included in the "group Stem Cells (SC)". The other eight dogs that had IVDD for over 1 year with no previous surgical intervention were randomly divided into the "surgery + SC" group or the "surgery + placebo" group. For the assignment, four envelopes containing the word "cell therapy" inside and four containing the word "placebo" were produced and kept with one person on the team who managed the cells and delivered them during the experimental surgery. The owners chose one of the sealed envelopes and delivered it to the researcher, who prepared the syringe with either stem cells or saline solution. All the rest of the team members, including the PI, master's degree students, surgeon, person who evaluated the outcomes and owner, were blinded 
to the group assignment. At the end of the experiment, the groups to which the animals belonged were revealed.

The dogs were distributed among three groups:

"SC group" (n=4): where the epidural applications of stem cells were performed on days 0,15 and 45 in animals previously subjected to decompressive surgery;

"Surgery + SC" $(n=4)$ : where the stem cells were applied topically during decompressive surgery (day 0) and at 15 and 45 days after decompression by epidural injection, totaling 3 applications;

"Surgery + placebo" $(n=4)$ : The saline solution was applied under the same conditions as in the previous group.

Three months after the initial treatment, the MRI (magnetic resonance imaging) scans performed initially were repeated for comparison. Functional and neurological examinations repeated biweekly, as well as magnetic resonance imaging, provided qualitative results.

\section{Functional and Neurological Evaluation}

In addition to the detailed anamnesis and general clinical examination, the animals underwent biweekly functional and neurological evaluation, where their reflexes and motor abilities were scored based on the scale developed by Olby et al. ${ }^{4}$

A neurological exam was also performed, where we evaluated mental status and behavior (alert, depressed, stuporous, comatose), body posture (abnormal head position; abnormal posture, such as decerebrate or decerebellate rigidity, Schiff-Sherrington posture, kyphosis, lordosis, scoliosis, plantigrade, palmigrade), gait (lameness; ataxia; paresis/ paralysis; abnormal movements, such as tremor, myotonia, or myoclonus), postural reactions (proprioceptive positioning, hopping, placing response), and cranial nerves and spinal reflexes (muscle tone, muscle reflex, patellar reflex, withdrawal reflex, nociception, perineal reflex).

\section{Magnetic Resonance Imaging}

The imaging findings of discopathies were calcification of the disc or nucleus pulposus, which is associated with the development of the intervertebral foramina, reduction in the intervertebral space, and radiopacity of the intervertebral foramina. $^{30-35}$

For MRI exams, animals were previously anaesthetized and subjected to orotracheal intubation (propofol $6 \mathrm{mg} / \mathrm{kg} / \mathrm{EV}$, followed by maintenance with inhaled isoflurane $1 \%$ ). The animals were maintained on fluid therapy with saline solution and monitored throughout the procedure through capnography, pulse oximetry, invasive blood pressure monitoring and cardiorespiratory frequency on an electrocardiogram monitor.
Animals were placed in the lateral recumbency position in the equipment (Vet-MR Grande XP - Esaote S.p.A., 0.25 Tesla-strength - Florence, Italy). The following sequences were performed: sagittal fast spin echo T2 (FSE T2), sagittal fast fluid-attenuated inversion recovery (FLAIR), sagittal stir, transverse spin echo T2 (FSE T2), sagittal spin echo T2 (SE T1), sagittal gradient echo T2 (GE T2) and transverse spin echo T1 (SE T1) when there was a need for contrast application. In the sagittal sequences, the field of view (FOV) was approximately $24 \mathrm{~cm}$, with 3 -millimetre-thick slices and 0 space, while in the transverse sequences, the FOV was approximately $20 \mathrm{~cm}$, with $4 \mathrm{~mm}$ slices and 0 space.

\section{Cell Therapy}

Immediately after the MRI, the animals in the "SC group", which had been subjected to previous decompressive surgery, underwent the placement of epidural catheters in the lumbosacral space. A confirmation of the Tuohy needle placement in the lumbosacral epidural space was performed through the "loss of resistance" and "drop" tests. The catheter was filled with saline solution and introduced into the site of the lesion where $2 \times 10^{6}$ stem cells were injected, as observed in Figure 2A.

In dogs that underwent surgery, the "surgery + SC" group, the first application of $2 \times 10^{6}$ stem cells was performed by dripping on the lesion during the procedure, followed by two epidural applications fifteen and fortyfive days after surgical decompression. In dogs in the "surgery + placebo" group, only $1 \mathrm{~mL}$ of saline solution was applied under the same conditions as in the previous group. Applications were performed in the L7-S1 intervertebral space, as shown in Figure $2 \mathrm{~B}$ and $\mathrm{C}$.

\section{Decompressive Surgical Procedure}

Standard protocols of analgesia and anesthesia (propofol $6 \mathrm{mg} / \mathrm{kg} / \mathrm{EV}$, followed by maintenance with inhaled isoflurane $1 \%$ ) were followed for surgical techniques and postoperative recovery.

In all animals in the "surgery + placebo" and "surgery + SC" groups, the hemilaminectomy procedure was performed, since it is the most commonly used technique in cases of thoracolumbar syndromes; it is associated with better spinal cord decompression results and removal of extruded material, as well as higher rates of postoperative neurological recovery, a lower risk of fibrosis formation, and lower rates of mechanical instability. ${ }^{1}$

The surgical procedure was based on the removal of the lateral and dorsolateral lamina, pedicles and articular 

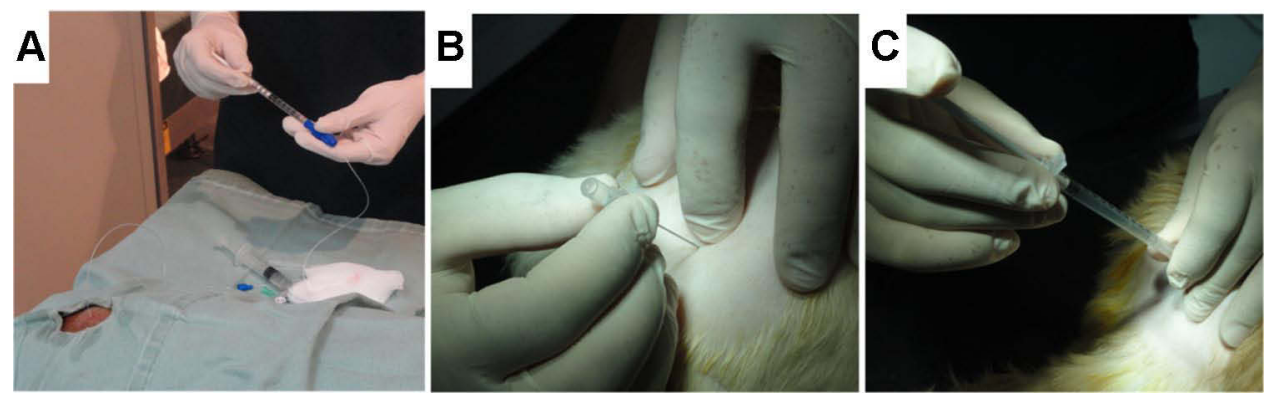

Figure 2 Cell therapy. (A) catheter introduced into the site of the lesion for cell injection. (B) The "hanging drop" technique, to identify the position of the needle tip within the extradural space. (C) Stem cells diluted in I $\mathrm{mL}$ applied into the extradural space.

facets. When access was achieved, the spinal cord was exposed to achieve good visualization of the nerves and vessels, allowing delicate and safe removal of only the extruded material and avoiding manipulation of the spinal cord. $^{36}$

After the procedure, the animals remained under observation until recovery from anesthesia, and then, they were discharged with prescriptions for anti-inflammatory agents and oral analgesics (Tramadol $4 \mathrm{mg} / \mathrm{kg}$; dexamethasone $1 \mathrm{mg} / \mathrm{kg}$; Ranitidine 2mg/kg; Cephalexin 20mg/kg). The postoperative recovery was monitored at a distance, and after 15 days, the animals returned to the clinic for suture removal and a second application of solution.

\section{Results}

All the stem cells used in the present study were obtained from a single bitch with a total of six fetuses, all in the final gestational stage. A dissection of the amniotic membrane was performed. All protocols to characterize and evaluate the quality of cells were performed routinely by our group. The cells were cryopreserved in the second passage in a total of 52 cryotubes, which remained in liquid nitrogen until use.

From May to July 2016, more than 200 owners of paraplegic dogs signed up to voluntarily participate in the project. A pre-screening was performed through a review of the patient history and previous exams. Of these, more than 40 were selected for preliminary functional and neurological evaluation. Twelve animals were selected according to the similarity of clinical signs and at least 12 months of chronicity (Table 1).

Of the twelve selected animals, three dogs were withdrawn from the study, and one dog had a car accident and was eliminated from the project, as shown in Figure 3. Therefore, eight selected dogs completed the proposed protocol, 4 males and 4 females, of mixed breeds and small size, with paraplegia secondary to thoracolumbar disc herniation and the absence of deep pain. The oldest animal was 10 years old, and the youngest was 3 years old. All patients had paraplegia for an average of 1 year and 4 months at the time of selection.

All animals subjected to surgery and/or stem cell application presented no adverse effects, tumors or worsening of the condition.

\section{Outcomes}

First, the animals were evaluated biweekly. However, most of the owners did not attend the scheduled dates, so some animals were evaluated every three weeks. This pattern of evaluation was not detrimental, since even after a longer period, the results remained the same as those of previous evaluations. Four animals in the SC group initially had an Olby scale score of 0 . As shown in the chart below, one of the animals progressed to score 8 , as it reacquired the deep pain reflex and was able to perform protraction with weight support more than $50 \%$ of the time, while animal 2 presented voluntary tail movement.

One of the animals subjected to surgery and cell therapy did not show any improvement. The other animal showed significant improvement, managed to put himself in position to feed himself and took some voluntary steps when supported, even without being fed. He was referred to physical therapy after the project and has been making progress.

Among the animals that received the placebo solution after the surgical procedure, no neurological improvement according to Olby's scale was noticed. However, one of the animals started to drag differently, presenting scabs in places where they had not previously. The owners of this dog still reported that the dog started to "warn" when there was a need to urinate.

All those clinical outcomes are expressed in Figure 4. 
Table I Demographic Distribution of Selected Animals

\begin{tabular}{|c|c|c|c|c|c|c|c|c|}
\hline Group & Animal & Gender & $\begin{array}{l}\text { Age } \\
\text { (YO) }\end{array}$ & $\begin{array}{l}\text { Location of } \\
\text { IVDD }\end{array}$ & $\begin{array}{l}\text { Chronicity } \\
\text { (M) }\end{array}$ & $\begin{array}{l}\text { Olby Score } \\
\text { Day } 0\end{array}$ & $\begin{array}{l}\text { Olby Score } \\
\text { Day } 90\end{array}$ & Outcome \\
\hline SC & $\begin{array}{l}1 \\
2 \\
3 \\
4\end{array}$ & $\begin{array}{l}F \\
M \\
M \\
F\end{array}$ & $\begin{array}{l}8 \\
5 \\
3 \\
10\end{array}$ & $\begin{array}{l}\text { L3-4 } \\
\text { L2-3/L3-4 } \\
\text { TI2-I3 } \\
\text { TI0-II }\end{array}$ & $\begin{array}{l}14 \\
12 \\
17 \\
12\end{array}$ & $\begin{array}{l}0 \\
0 \\
0 \\
0\end{array}$ & $\begin{array}{l}0 \\
4 \\
10 \\
0\end{array}$ & $\begin{array}{l}\text { No improvement } \\
\text { Improved } \\
\text { Improved } \\
\text { No improvement }\end{array}$ \\
\hline SURGERY + SC & $\begin{array}{l}5 \\
6 \\
7 \\
8\end{array}$ & $\begin{array}{l}F \\
F \\
M \\
M\end{array}$ & $\begin{array}{l}7 \\
10 \\
7 \\
13\end{array}$ & $\begin{array}{l}\text { TII-I2/TI3-LI } \\
\text { TII-I2 } \\
\text { L3-4 } \\
\text { L2-3 }\end{array}$ & $\begin{array}{l}14 \\
12 \\
18 \\
13\end{array}$ & $\begin{array}{l}0 \\
0 \\
0 \\
0\end{array}$ & $\begin{array}{l}0 \\
9 \\
- \\
-\end{array}$ & $\begin{array}{l}\text { No improvement } \\
\text { Improved } \\
\text { Withdrawn } \\
\text { Excluded }\end{array}$ \\
\hline $\begin{array}{l}\text { SURGERY + } \\
\text { PLACEBO }\end{array}$ & $\begin{array}{l}9 \\
10 \\
11 \\
12\end{array}$ & $\begin{array}{l}M \\
M \\
M \\
F\end{array}$ & $\begin{array}{l}4 \\
3 \\
7 \\
5\end{array}$ & $\begin{array}{l}\text { TII-I2/TI3-LI } \\
\text { TI2-I3 } \\
\text { TI2-I3/TI3-LI } \\
\text { LI-2/L2-3 }\end{array}$ & $\begin{array}{l}16 \\
15\end{array}$ & $\begin{array}{l}0 \\
0 \\
0 \\
0\end{array}$ & $\begin{array}{l}0 \\
0 \\
- \\
-\end{array}$ & $\begin{array}{l}\text { No improvement } \\
\text { No improvement } \\
\text { Withdrawn } \\
\text { Withdrawn }\end{array}$ \\
\hline
\end{tabular}

Abbreviations: SC, stem cell; M, male; F, female; yo, years old; IVDD, intervertebral disc disease; m, months.

\section{Magnetic Resonance Imaging}

In MRI scans of the group that had previously undergone the surgical procedure (Figure 5), it was possible to observe hypo- and hyperintense areas through the dorsal soft tissues, suggestive of the surgical scar, and the loss of signal intensity from the nucleus pulposus of intervertebral discs, suggesting dehydration and disc degeneration. In some of the animals, it was still possible to observe the loss of the definition of the ventral column of the cerebrospinal fluid and dorsal displacement of the adjacent spinal cord, characteristic of disc protrusion, even after the previous decompression procedure. There was no change in the images taken after D90 in this group.

In all the animals that underwent the decompression procedure, a metal-compatible image artefact was observed. This image artefact possibly resulted from filings derived from the wear of the surgical milling cutter in contact with the free stripper, used to prevent and protect structures during bone wear. Because of this artefact, the images were inappropriate for evaluation.

\section{Clinical Outcomes}

As observed in Supplementary Video S1, prior to cell therapy, the animal had no deep pain or proprioception. Ninety days after the application of stem cells, the animal regained nociception and proprioception, which allowed him to walk again. The dog was referred to physical therapy, where it remains in treatment to improve its movements.

\section{Discussion}

Stem cells receive a great deal of attention because of their regenerative potential and their possible use in regenerative therapy, including xenogeneic transplants, ${ }^{37-39}$ due to their immunomodulatory properties, which are also therapeutic assets. ${ }^{40}$ Stem cells have shown promising results in several species and in spinal cord injuries. ${ }^{10-13}$

Amniotic membrane stem cells are easy to obtain, culture, expand and use ${ }^{15,41,42}$ they involve little ethical concern since they are derived from a material that is discarded, and their use for research purposes can possibly be expanded to human species. They present good results when used in the treatment of chronic kidney disease, ${ }^{43}$ infertility, ${ }^{44}$ ophthalmic lesions, ${ }^{45,46}$ burns and skin wounds, ${ }^{47,48}$ osteoarthritis, ${ }^{49}$ fasciitis and tendinitis, ${ }^{50}$ ligament injuries ${ }^{51}$ and nervous pathologies. ${ }^{52}$ However, this cell type is still little explored in the treatment of spinal cord injuries in dogs, ${ }^{37,39}$ and our work is the first to use them in dogs with chronic, non-iatrogenic intervertebral disc disease.

Many papers used the lineage previously characterized, which proved to be safe for in vivo application. ${ }^{27,53}$ The animals in the present study were followed up, even after 90 days. To date, cell therapy has proven to be feasible, with no adverse effects.

In a study conducted by Sankar et $\mathrm{a}^{37}$ the efficiency of stem cells derived from the human amniotic membrane was tested when applied in iatrogenic spinal cord injury in monkeys. Good interaction of the cells with the nervous tissue and significant remyelination, as well as their 


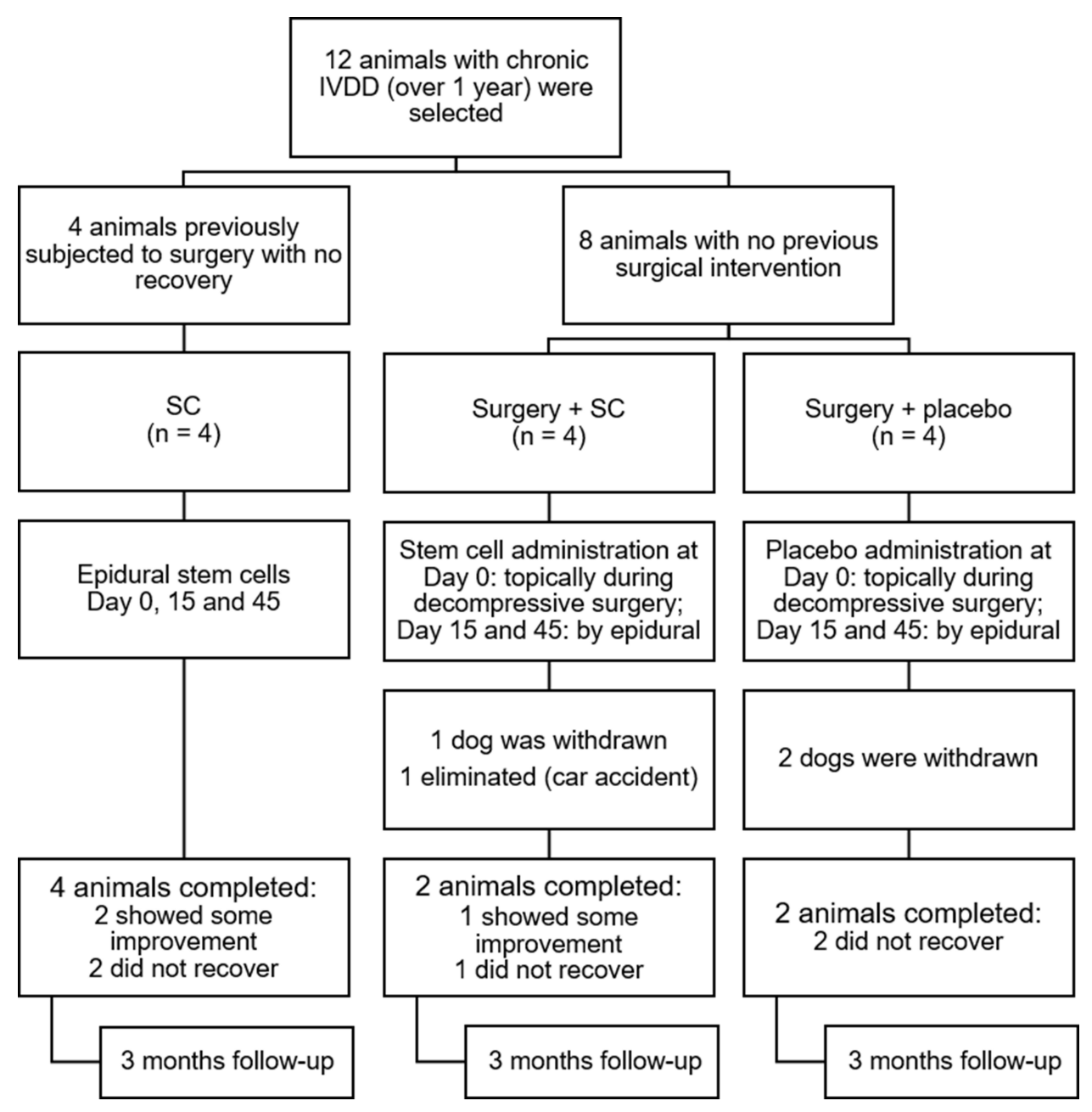

Figure 3 Diagram of protocol: Experimental design and group organization.

capacity to modulate the glial scar, were observed; however, no clinical improvement was observed at the 60-day evaluation.

A similar study, conducted by $\mathrm{Wu}$ et $\mathrm{al}^{54}$ evaluated the application of the same cells in rats. The histopathological findings were similar; however, the animals showed clinical improvement, including a return of the motor function of the pelvic limbs.

Nevertheless, Meng et $\mathrm{al}^{39}$ confirmed, through electrophysiological and immunohistological analysis, the success of the co-transplantation of stem cells from the amniotic membrane of rats with fibroblast growth factor and stem cells of neuronal origin in rats with chronic spinal cord injury. The results demonstrated that there was significant locomotor improvement in addition to neuronal survival and differentiation, suggesting that these sources may be beneficial in the treatment of spinal cord injuries. Hemilaminectomy is an elective procedure since it preserves the mechanical and structural integrity of the spine, is less traumatic, and reduces the chances of scar formation that compresses the spinal cord. In addition, access to the disc is better, and fenestration is performed in an easier way. ${ }^{36,55}$

The fenestration of the affected disc, as well as the discs anterior and posterior to it, is still a discussion among authors and surgeons. While some consider it the appropriate practice, as it allows the removal of remnants of the extruded material in the intervertebral space and the prevention of the recurrence of the frame, ${ }^{1,56,57}$ others consider it unnecessary, since the recurrence rate of herniation in animals that have not undergone fenestration is rare (less than 5\%). Among the animals that had already undergone decompression procedures, none experienced disc fenestration, and two presented significant improvements. However, on magnetic resonance imaging, it was possible to observe that there were still signs of compression, which may have impaired their improvement. 


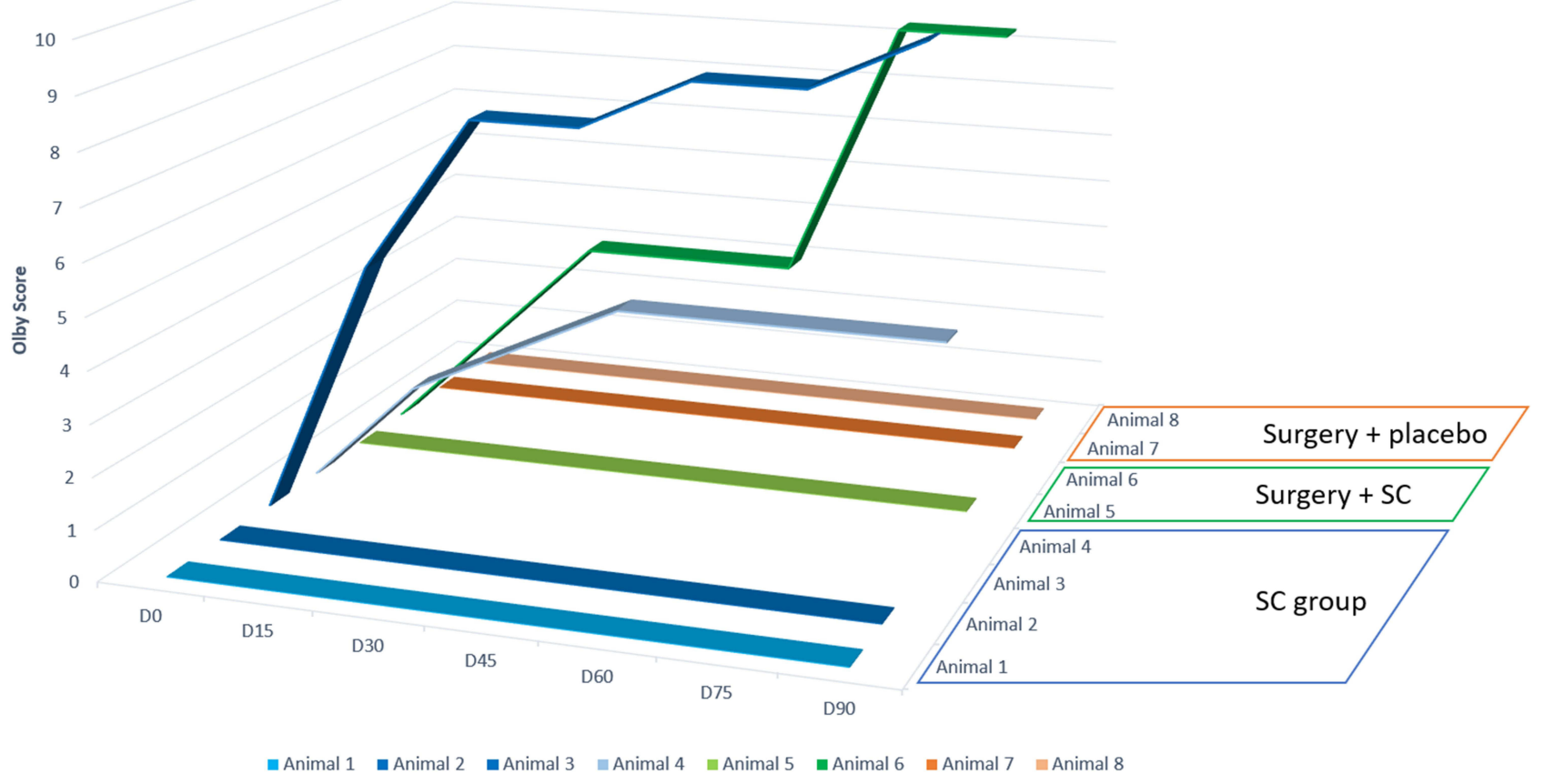

Figure 4 Clinical outcomes. Clinical outcomes of all the animals, were animal I-4 represents SC group; animal 5-6 are from surgery + SC; and animal 7-8 are surgery + placebo group.
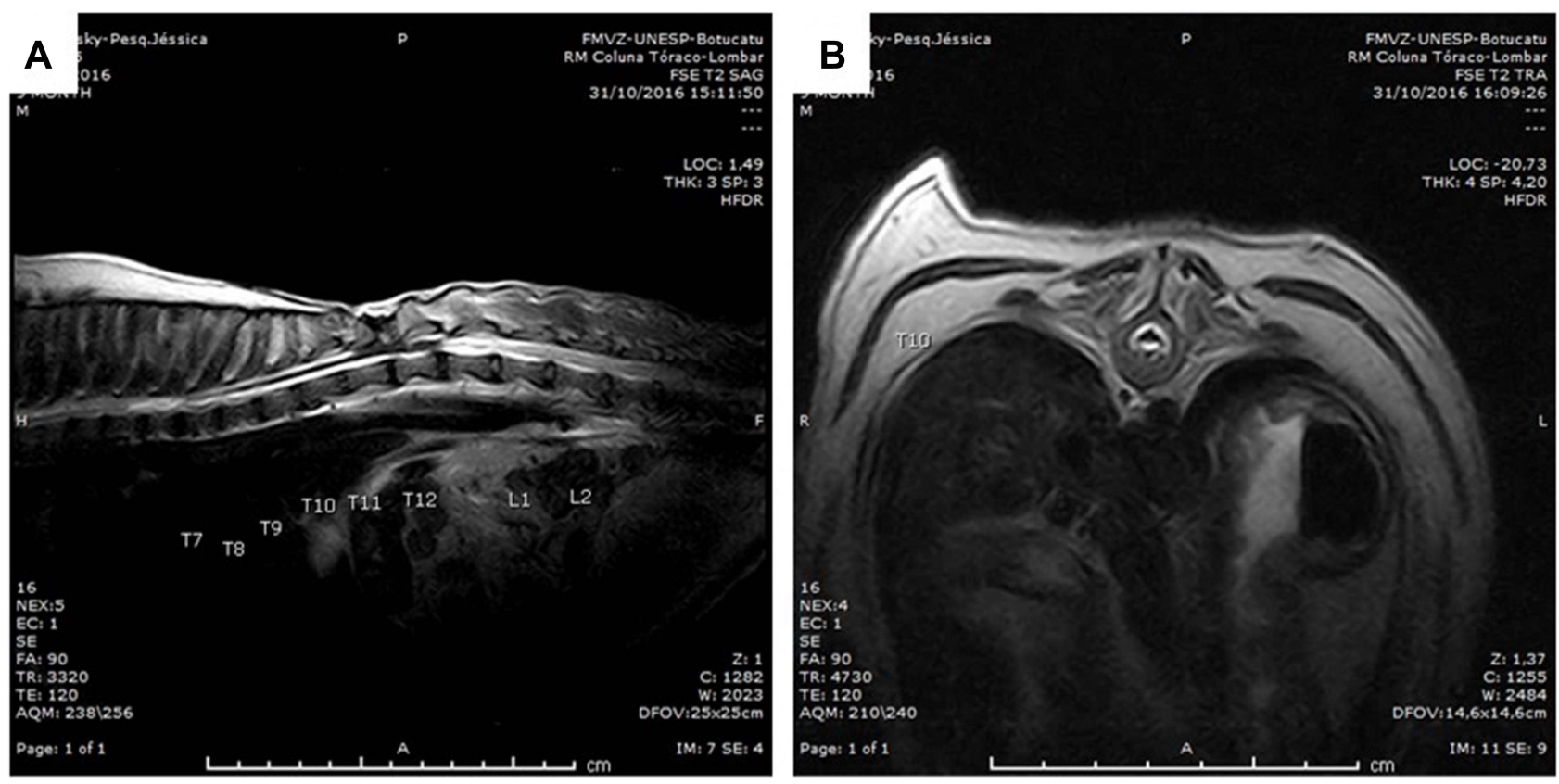

Figure 5 Magnetic resonance imaging. Significant areas of hypointense signal and disc degeneration in the sagittal (A) and transverse (B) sections from animals from the surgery group.

Many professionals still believe that decompression is ineffective if it occurs after a period of 72 hours after the loss of nociception. Such a belief has already been disproven by studies such as those of Scott and McKee, ${ }^{58}$
Olby et al ${ }^{59}$ Kazakos et $\mathrm{al}^{60}$ and Arias et al. ${ }^{61}$ One of the animals that received the stem cell solution after surgery presented improvement. However, due to the small sample size, we cannot determine whether this improvement was 
due to the decompression procedure, cellular therapy or the combination of both.

Animals with chronic lesions, in addition to the glial scar, which is an anatomical barrier to nerve regeneration, ${ }^{62}$ also have evident muscular deficits. The animals that presented neurological improvement could have recovered voluntary movement if they had undergone physiotherapy and exercises to gain muscle mass. ${ }^{63}$

Unfortunately, even after very rigorous selection, some owners chose to withdraw from the project for several reasons. This left us with an even smaller sample. However, due to the high costs of the exams and procedures involved in the project, it would not be possible to achieve the necessary sample size for the results to be statistically significant. Therefore, there is a need for more studies to prove that the therapy is, in fact, beneficial. Even in randomized studies performed at exemplary institutions by experienced researchers, the desired sample size was not reached. For example, in research conducted by $\operatorname{Lim}$ et $\mathrm{al}^{64}$ only 13 of the 19 dogs completed the project; in a study conducted by Tsai et al ${ }^{65} 36$ out of 40 completed the project; and in a study conducted by Olby et $\mathrm{al}^{66} 94$ of $150 \mathrm{dogs}$ completed the project. Another recent experiment in dogs showed tooth stem cells were associated with electroacupuncture with benefits to the animals. ${ }^{67}$

However, when the owners are provided clarifications about the risks, odds and benefits involved with the therapy, even if there are animals that do not show improvement, this type of alternative therapy is worth pursuing in an attempt to at least promote the well-being of these animals and restore some physiological functions.

\section{Conclusion}

The protocol of preclinical trial showed feasible to create a canine amniotic membrane stem cell bank from the final gestational stage.

The protocol associated with decompressive surgery and cell transplantation in these dogs with chronic thoracolumbar IVDD proved feasible, and it was possible to observe neurological improvement in some animals after treatment, such as proprioceptive ability and the return of nociception.

It was not possible to analyze the tissue improvement through MRI, since the surgery resulted in artefacts of images that did not allow its evaluation.

Despite being very laborious, the performance of the double-blind test guaranteed reliability of the evaluations and results obtained that, even with a small sample size, generated satisfactory results for the team and the owners. Further research is needed with a larger number of animals but this blinded preclinical trial showed improved of quality life in animal and owners.

\section{Data Sharing Statement}

The data used to support the findings of this study are available from the authors (Orlandin and Ambrosio) upon request.

\section{Acknowledgments}

We thank National Council for the Improvement of Higher Education (CAPES: Coordenação de Aperfeiçoamento de Pessoal de Nível Superior - Brasil - Código de Financiamento 001), CNPq and the São Paulo Research Foundation (FAPESP) for providing MRI equipment through Process 2009/54028-8 and for the financial support (Grant number 2017/21266-0).

We also thank Heraldo André Catalan Rosa, Ivânio Teixeira de Borba Júnior, Prof. Dr. Francisco José Teixeira Neto, Carolina Hagy Girotto and the anaesthetic team from Unesp Botucatu and the anaesthetic and surgical team from FZEA-USP for support during the MRI exams, surgeries and cell therapy.

\section{Disclosure}

The authors report no conflicts of interest in this work.

\section{References}

1. Brisson BA. Intervertebral disc disease in dogs. Vet Clin North Am Small Anim Pract. 2010;40(5):829-858. doi:10.1016/j.cvsm.2010. 06.001

2. Hansen H. A pathologic-anatomical study on disc degeneration in dog, with special reference to the so-called enchondrosis intervertebralis. Acta Orthop Scand Suppl. 1952;11:1-117. doi:10.3109/ort.1952.23. suppl-11.01

3. Fenn J, Olby NJ. Classification of intervertebral disc disease. Front Vet Sci. 2020;7. doi:10.3389/fvets.2020.579025

4. Olby NJ, De Risio L, Muñana KR, et al. Development of a functional scoring system in dogs with acute spinal cord injuries. Am J Vet Res. 2001;62(10):1624-1628. doi:10.2460/ajvr.2001.62.1624

5. Bezerra CH, Lopes RS, Franco A, et al. Levantamento de casos de janeiro a junho de 2012 atendidos na FisioCare Pet. Rev Educ Contin Med Vet Zoot CRMV-SP. 2013;11(2):71.

6. Caplan AI. Mesenchymal stem cells. J Orthop Res. 1991;9(5):641-650. doi:10.1002/jor.1100090504

7. Dominici M, Le Blanc K, Mueller I, et al. Minimal criteria for defining multipotent mesenchymal stromal cells. The international society for cellular therapy position statement. Cytotherapy. 2006;8(4):315-317. doi:10.1080/14653240600855905

8. Nishida H, Nakayama M, Tanaka H, et al. Safety of autologous bone marrow stromal cell transplantation in dogs with acute spinal cord injury. Vet Surg. 2012;41(4):437-442. doi:10.1111/j.1532-950X.2011. 00959.x 
9. Bydlowski SP, Debes AA, Maselli LMF, Janz FL. Características biológicas das células-tronco mesenquimais. Rev Bras Hematol Hemoter. 2009;31:25-35. doi:10.1590/S1516-84842009005000038

10. Sarmento C, Rodrigues M, Bocabello R, Mess A, Miglino M. Pilot study: bone marrow stem cells as a treatment for dogs with chronic spinal cord injury. Regen Med Res. 2014;2(1):9. doi:10.1186/2050-490X-2-9

11. Lee SH, Kim Y, Rhew D, et al. Effect of the combination of mesenchymal stromal cells and chondroitinase $\mathrm{ABC}$ on chronic spinal cord injury. Cytotherapy. 2015;17(10):1374-1383. doi:10.10 16/j.jcyt.2015.05.012

12. Hoffman AM, Dow SW. Concise review: stem cell trials using companion animal disease models. Stem Cells. 2016;34 (7):1709-1729. doi:10.1002/stem.2377

13. Feitosa MLT, Sarmento CAP, Bocabello RZ, et al. Transplantation of human immature dental pulp stem cell in dogs with chronic spinal cord injury. Acta Cir Bras. 2017;32(7):540-549. doi:10.1590/s0102865020170070000005

14. Escalhão CCM, Ramos IP, Hochman-Mendez C, et al. Safety of allogeneic canine adipose tissue-derived mesenchymal stem cell intraspinal transplantation in dogs with chronic spinal cord injury. Stem Cells Int. 2017;2017:1-11. doi:10.1155/2017/3053759

15. Ambrosio CE, Orlandin JR, Oliveira VC, et al. Potential application of aminiotic stem cells in veterinary medicine. Anim Reprod. 2018;16:24-30. Colegio Brasileiro de Reproducao Animal. doi:10.21451/1984-3143-AR2018-0124

16. Bach FS, Rebelatto CLK, Fracaro L, et al. Comparison of the efficacy of surgical decompression alone and combined with canine adipose tissue-derived stem cell transplantation in dogs with acute thoracolumbar disk disease and spinal cord injury. Front Vet Sci. 2019;6. doi: 10.3389 /fvets. 2019.00383

17. Wu GH, Shi HJ, Che MT, et al. Recovery of paralyzed limb motor function in canine with complete spinal cord injury following implantation of MSC-derived neural network tissue. Biomaterials. 2018;181:15-34. doi:10.1016/j.biomaterials.2018.07.010

18. Bhat IA, Sivanarayanan TB, Somal A, et al. An allogenic therapeutic strategy for canine spinal cord injury using mesenchymal stem cells. J Cell Physiol. 2019;234(3):2705-2718. doi:10.1002/jcp.27086

19. Aralla M, Groppetti D, Caldarini L, Cremonesi F, Arrighi S. Morphological evaluation of the placenta and fetal membranes during canine pregnancy from early implantation to term. Res Vet Sci. 2013;95(1):15-22. doi:10.1016/j.rvsc.2013.02.003

20. Huo S, Shi P, Pang X. Culture and identification of human amniotic mesenchymal stem cells. Chin Med Sci J. 2010;25(4):211-214. doi:10.1016/S1001-9294(11)60004-7

21. Cremonesi F, Corradetti B, Lange Consiglio A. Fetal adnexa derived stem cells from domestic animal: progress and perspectives. Theriogenology. 2011;75(8):1400-1415. doi:10.1016/j.theriogenology. 2010.12.032

22. Filioli Uranio M, Valentini L, Lange-Consiglio A, et al. Isolation, proliferation, cytogenetic, and molecular characterization and in vitro differentiation potency of canine stem cells from foetal adnexa: a comparative study of amniotic fluid, amnion, and umbilical cord matrix. Mol Reprod Dev. 2011;78(5):361-373. doi:10.1002/mrd.21311

23. Fernandes RA, Wenceslau CV, Reginato AL, Kerkis I, Miglino MA. Derivation and characterization of progenitor stem cells from canine allantois and amniotic fluids at the third trimester of gestation. Placenta. 2012;33(8):640-644. doi:10.1016/J.PLACENTA.2012.03.009

24. Lange-Consiglio A, Corradetti B, Bizzaro D, et al. Characterization and potential applications of progenitor-like cells isolated from horse amniotic membrane. J Tissue Eng Regen Med. 2012;6(8):622-635. doi: $10.1002 /$ term. 465

25. Lange-Consiglio A, Corradetti B, Meucci A, Perego R, Bizzaro D, Cremonesi F. Characteristics of equine mesenchymal stem cells derived from amnion and bone marrow: in vitro proliferative and multilineage potential assessment. Equine Vet J. 2013;45(6):737-744. doi:10.1111/evj.12052
26. Vidane AS, Souza AF, Sampaio RV, et al. Cat amniotic membrane multipotent cells are nontumorigenic and are safe for use in cell transplantation. Stem Cells Cloning. 2014;7:71-78. doi:10.2147/ SCCAA.S67790

27. Cardoso M, Pinheiro A, Vidane A, et al. Characterization of teratogenic potential and gene expression in canine and feline amniotic membrane-derived stem cells. Reprod Domest Anim. 2017;52:58-64. doi:10.1111/rda. 12832

28. de Oliveira Pinheiro A, Lara VM, Souza AF, et al. Characterization and immunomodulation of canine amniotic membrane stem cells. Stem Cells Cloning Adv Appl. 2020;13:43-55. doi:10.2147/SCCAA. S237686

29. Soncini M, Vertua E, Gibelli L, et al. Isolation and characterization of mesenchymal cells from human fetal membranes. J Tissue Eng Regen Med. 2007;1(4):296-305. doi:10.1002/term.40

30. Lamb CR. Common difficulties with myelographic diagnosis of acute intervertebral disc prolapse in the dog. J Small Anim Pract. 1994;35 (11):549-558. doi:10.1111/j.1748-5827.1994.tb03816.x

31. Bagley RS, Harrington ML, Silver GM, Cambridge AJ, Connors RL. Exogenous spinal trauma: clinical assessment and initial management. Compend Contin Educ Vet. 1999;21:1138-1144.

32. Lewis MJ, Cohen EB, Olby NJ. Magnetic resonance imaging features of dogs with incomplete recovery after acute, severe spinal cord injury. Spinal Cord. 2018;56(2):133-141. doi:10.1038/s41393-0170004-8

33. Rosenblatt AJ, Bottema CDK, Hill PB. Radiographic scoring for intervertebral disc calcification in the dachshund. Vet J. 2014;200 (3):355-361. doi:10.1016/j.tvj1.2014.03.023

34. Olby NJ, Dyce J, Houlton JEF. Correlation of plain radiographic and lumbar myelographic findings with surgical findings in thoracolumbar disc disease. J Small Anim Pract. 1994;35(7):345-350. doi:10.1111/j.1748-5827.1994.tb01713.x

35. Neshat Halati F, Vajhi A, Molazem M, Dehghan MM, Ansari F. Are magnetic resonance imaging or radiographic findings correlated with clinical prognosis in spinal cord neuropathy? Vet Res Forum an Int $Q J .2016 ; 7(3): 261-266$.

36. Downes CJ, Gemmill TJ, Gibbons SE, McKee WM. Hemilaminectomy and vertebral stabilisation for the treatment of thoracolumbar disc protrusion in 28 dogs. J Small Anim Pract. 2009;50(10):525-535. doi:10.1111/j.1748-5827.2009.00808.x

37. Sankar V, Muthusamy R. Role of human amniotic epithelial cell transplantation in spinal cord injury repair research. Neuroscience. 2003;118(1):11-17. doi:10.1016/S0306-4522(02)00929-6

38. Yazdani SO, Pedram M, Hafizi M, et al. A comparison between neurally induced bone marrow derived mesenchymal stem cells and olfactory ensheathing glial cells to repair spinal cord injuries in rat. Tissue Cell. 2012;44(4):205-213. doi:10.1016/j.tice.2012.03.003

39. Meng X, Li C, Dong Z, et al. Co-transplantation of bFGF-expressing amniotic epithelial cells and neural stem cells promotes functional recovery in spinal cord-injured rats. Cell Biol Int. 2008;32 (12):1546-1558. doi:10.1016/j.cellbi.2008.09.001

40. Orlandin JR, Ambrósio CE, Lara VM. Glial scar-modulation as therapeutic tool in spinal cord injury in animal models. Acta Cir Bras. 2017;32(2):168-174. doi:10.1590/s0102-865020170209

41. Wenceslau CV, Miglino MA, Martins DS, et al. Mesenchymal progenitor cells from canine fetal tissues: yolk sac, liver, and bone marrow. Tissue Eng Part A. 2011;17(17-18):2165-2176. doi:10.1089/ten.TEA.2010.0678

42. Park S-B, Seo M-S, Kim H-S, Kang K-S, Bauer JA. Isolation and characterization of canine amniotic membrane-derived multipotent stem cells. Bauer JA, ed. PLoS One. 2012;7(9):e44693. doi:10.1371/journal.pone. 0044693

43. Vidane A, Pinheiro A, Casals J, et al. Transplantation of amniotic membrane-derived multipotent cells ameliorates and delays the progression of chronic kidney disease in cats. Reprod Domest Anim. 2017;52(S2):316-326. doi:10.1111/rda.12846 
44. Fouad H, Sabry D, Elsetohy K, Fathy N. Therapeutic efficacy of amniotic membrane stem cells and adipose tissue stem cells in rats with chemically induced ovarian failure. $J$ Adv Res. 2016;7 (2):233-241. doi:10.1016/j.jare.2015.05.002

45. Kim JS, Kim JC, Hahn TW, Park WC. Amniotic membrane transplantation in infectious corneal ulcer. Cornea. 2001;20(7):720-726. doi:10.1097/00003226-200110000-00010

46. Chen H-C, Tan H-Y, Hsiao C-H, Huang SC-M, Lin -K-K, Ma DH-K. Amniotic membrane transplantation for persistent corneal ulcers and perforations in acute fungal keratitis. Cornea. 2006;25(5):564-572. doi:10.1097/01.ico.0000227885.19124.6f

47. Salehi SH, As'adi K, Mousavi SJ, Shoar S. Evaluation of amniotic membrane effectiveness in skin graft donor site dressing in burn patients. Indian J Surg. 2015;77(S2):427-431. doi:10.1007/s12262013-0864-x

48. ElHeneidy H, Omran E, Halwagy A, Al-Inany H, Al-Ansary M, Gad A. Amniotic membrane can be a valid source for wound healing. Int $J$ Womens Health. 2016;8:225-231. doi:10.2147/IJWH.S96636

49. Vines J, Aliprantis A, Gomoll A, Farr J. Cryopreserved amniotic suspension for the treatment of knee osteoarthritis. J Knee Surg. 2015;29(06):443-450. doi:10.1055/s-0035-1569481

50. Werber B. Amniotic tissues for the treatment of chronic plantar fasciosis and achilles tendinosis. J Sport Med (Hindawi Publ Corp. 2015;2015:219896. doi:10.1155/2015/219896

51. Lange-Consiglio A, Tassan S, Corradetti B, et al. Investigating the efficacy of amnion-derived compared with bone marrow-derived mesenchymal stromal cells in equine tendon and ligament injuries. Cytotherapy. 2013;15(8):1011-1020. doi:10.1016/j.jcyt.2013.03.002

52. Su C-F, Chang L-H, Kao C-Y, et al. Application of amniotic fluid stem cells in repairing sciatic nerve injury in minipigs. Brain Res. 2018;1678:397-406. doi:10.1016/j.brainres.2017.11.010

53. Winck CP, Amélia S, Lima F, et al. Células-tronco fetais de membrana amniótica: o futuro da medicina regenerativa [Amniotic membrane fetal stem cells: the future of regenerative medicine]. REB. 2014;7(3):321-329. Portuguese.

54. Wu Z, Hui G, Lu Y, Wu X, Guo L. Transplantation of human amniotic epithelial cells improves hindlimb function in rats with spinal cord injury. Chin Med J. 2006;119(24):2101-2107. doi:10.1097/00029330-200612020-00013

55. Fenn J, Laber E, Williams K, et al. Associations between anesthetic variables and functional outcome in dogs with thoracolumbar intervertebral disk extrusion undergoing decompressive hemilaminectomy. J Vet Intern Med. 2017;31:3. doi:10.1111/jvim.14677

56. Forterre F, Konar M, Spreng D, Jaggy A, Lang J. Influence of intervertebral disc fenestration at the herniation site in association with hemilaminectomy on recurrence in chondrodystrophic dogs with thoracolumbar disc disease: a Prospective MRI Study. Vet Surg. 2008;37(4):399-405. doi:10.1111/j.1532-950X.2008.00394.x

57. Brisson BA, Moffatt SL, Swayne SL, Parent JM. Recurrence of thoracolumbar intervertebral disk extrusion in chondrodystrophic dogs after surgical decompression with or without prophylactic fenestration: 265 cases (1995-1999). J Am Vet Med Assoc. 2004;224 (11):1808-1814. doi:10.2460/javma.2004.224.1808
58. Scott HW, McKee WM. Laminectomy for 34 dogs with thoracolumbar intervertebral disc disease and loss of deep pain perception. J Small Anim Pract. 1999;40(9):417-422. doi:10.1111/j.17485827.1999.tb03114.x

59. Olby N, Levine J, Harris T, Muñana K, Skeen T, Sharp N. Long-term functional outcome of dogs with severe injuries of the thoracolumbar spinal cord: 87 cases (1996-2001). J Am Vet Med Assoc. 2003;222 (6):762-769. doi:10.2460/javma.2003.222.762

60. Kazakos G, Polizopoulou ZS, Patsikas MN, Tsimopoulos G, Roubies N, Dessiris A. Duration and severity of clinical signs as prognostic indicators in 30 dogs with thoracolumbar disk disease after surgical decompression. $J$ Vet Med Ser A. 2005;52(3):147-152. doi:10.1111/j.1439-0442.2005.00698.x

61. Arias MVB, Nishioka CM, Garcia CO, Reia AZ, Baraúna Júnior D, Marcasso RA. Avaliação dos resultados clínicos após cirurgia descompressiva em cães com doença de disco intervertebral [Evaluation of clinical results after descompression surgery in dogs with intervertebral disc disease]. Arq Bras Med Vet Zootec. 2007;59 (6):1445-1450. Portuguese. doi:10.1590/S0102-0935 2007000600015

62. Olson L. Medicine: clearing a path for nerve growth. Nature. 2002;416(6881):589-590. doi:10.1038/416589a

63. Bennaim M, Porato M, Jarleton A, et al. Preliminary evaluation of the effects of photobiomodulation therapy and physical rehabilitation on early postoperative recovery of dogs undergoing hemilaminectomy for treatment of thoracolumbar intervertebral disk disease. Am $J$ Vet Res. 2017;78(2):195-206. doi:10.2460/ajvr. 78.2.195

64. Lim J-H, Muguet-Chanoit AC, Smith DT, Laber E, Olby NJ. Potassium channel antagonists 4-aminopyridine and the T-butyl carbamate derivative of 4-aminopyridine improve hind limb function in chronically non-ambulatory dogs; A blinded, placebo-controlled trial. Sabaawy HE, ed. PLoS One. 2014;9(12):e116139. doi:10.1371/journal.pone.0116139

65. Tsai L-C, Lin Y-W, Hsieh C-L. Effects of bee venom injections at acupoints on neurologic dysfunction induced by thoracolumbar intervertebral disc disorders in canines: a Randomized, Controlled Prospective Study. Biomed Res Int. 2015;2015:1-7. doi:10.1155/ $2015 / 363801$

66. Olby NJ, Vaden SL, Williams K, et al. Effect of cranberry extract on the frequency of bacteriuria in dogs with acute thoracolumbar disk herniation: a randomized controlled clinical trial. $J$ Vet Intern Med. 2017;31(1):60-68. doi:10.1111/jvim.14613

67. Prado C, Fratini P, de Sá Schiavo Matias G, et al. Combination of stem cells from deciduous teeth and electroacupuncture for therapy in dogs with chronic spinal cord injury: a pilot study. Res Vet Sci. 2019;123:247-251. doi:10.1016/j.rvsc.2019. 01.011

68. Pinto PAF, Pereira VM, Motta LCB, et al. Mammalian yolk sac - an alternative source of stem cells. Braz J Vet Med. 2021;43:e01221. doi:10.29374/2527-2179.bjvm001221

\section{Publish your work in this journal}

Stem Cells and Cloning: Advances and Applications is an international, peer-reviewed, open access journal. Areas of interest in established and emerging concepts in stem cell research include: Embryonic cell stems; Adult stem cells; Blastocysts; Cordblood stem cells; Stem cell transformation and culture; Therapeutic cloning; Umbilical cord blood and bone marrow cells; Laboratory, animal and human therapeutic studies; Philosophical and ethical issues related to stem cell research. This journal is indexed on CAS. The manuscript management system is completely online and includes a very quick and fair peer-review system, which is all easy to use. Visit http://www.dovepress.com/testimonials.php to read real quotes from published authors. 